\title{
Intra annual seed production and availability of two morphotypes of Brosimum rubescens taubert in forests of the Colombian Amazon
}

\author{
Luis Eduardo Rivera ${ }^{1}$, María Cristina Peñuela ${ }^{2}$ \& Flavio Moreno ${ }^{3,4}$ \\ ${ }^{1}$ Universidad Nacional de Colombia, Sede Amazonia, Leticia, Amazonas, Colombia. \\ ${ }^{1,2}$ Universidad Regional Amazónica IKIAM, Ciudad de Tena, Provincia de Napo, Ecuador. \\ ${ }^{3}$ Department of Forest Science, Universidad Nacional de Colombia Sede Medellín, Medellín, Colombia \\ ${ }^{4}$ Corresponding author: Flavio Moreno,e-mail: fhmoreno@unal.edu.co
}

RIVERA, L.E., PEÑUELA, M.C., MORENO, F. Intra annual seed production and availability of two morphotypes of Brosimum rubescens taubert in forests of the Colombian Amazon. Biota Neotropica. 14(4): e20130073. http://dx.doi.org/10.1590/1676-06032014007313

\begin{abstract}
We assessed the reproductive phenology, production, and availability of seeds for two morphotypes of Brosimum rubescens Taub. (Moraceae), locally known as black palosangre (BP) and white palosangre (WP) during an annual cycle in a 20-ha mega plot located in a primary forest at the El Zafire Biological Station, in the Colombian Amazon. We found that $87 \%$ and $41 \%$ of potentially reproductive individuals of $\mathbf{B P}$ and WP respectively, was fertile and the production of reproductive structures was variable within and between morphotypes. The phenological pattern was seasonal in both morphotypes, characterized by flowering at the end of the dry season and fruiting at the start of the rainy season. BP produced and aborted large amounts of infructescences (approximately 21743), possibly as a response to satiate predators. Relative predation in terms of pre-dispersion of seeds was similar in both morphotypes, with a greater damage generated by a Scolytidae Curculionidae (Coleoptera) and to a lesser degree by frugivorous vertebrates. The number of mature fruits, total seeds, and removed seeds was similar for both morphotypes. Differences in the amount of reproductive structures and in the timing of phenophases between morphotypes decreased the competition and contributed to their coexistence. It seems that in undisturbed forests seed limitation could be more conditioning for WP, while other limitations after fruit and seed production could occur in BP.
\end{abstract}

Keywords: Fecundity, predation, reproductive phenology, seed limitation, seed removal.

RIVERA, L.E., PEÑUELA, M.C., MORENO, F. Producción y disponibilidad intra anual de semillas de dos morfotipos de Brosimum rubescens Taubert en bosques de la amazonía colombiana. Biota Neotropica. 14(4): e20130073. http://dx.doi.org/10.1590/1676-06032014007313

Resumen: Se evaluó la fenología reproductiva, producción y disponibilidad de semillas de dos morfotipos de Brosimum rubescens Taub. (Moraceae), conocidos localmente como palosangre negro (PN) y palosangre blanco (PB), durante un ciclo anual en una megaparcela de 20 ha localizada en bosques primarios de la Estación Biológica El Zafire, Amazonía colombiana. Se encontró que estuvieron fértiles el $87 \%$ y $41 \%$ de los individuos potencialmente reproductivos de PN y PB, respectivamente. La producción de estructuras reproductivas fue variable dentro y entre morfotipos. El patrón fenológico fue estacional en ambos: florecieron al final de la época seca y fructificaron al inició de la lluviosa. Aunque en PB aparentemente ocurre limitación en la polinización, la maduración de los óvulos fecundados es más eficiente que en PN. Este último produjo y abortó abundante cantidad de infrutescencias, posiblemente para saciar depredadores. En ambos morfotipos la depredación relativa pre-dispersión de las semillas fue similar, siendo mayor el daño generado por un Curculionidae Scolytidae (Coleóptera) y menor por frugívoros vertebrados. El número de frutos maduros, semillas totales y semillas removidas también fue similar entre morfotipos. Diferencias en la cantidad de estructuras reproductivas y en el tiempo de manifestación de las fenofases entre morfotipos, disminuyen la competencia y contribuyen a su coexistencia. Aparentemente, en bosques no disturbados la limitación de semillas podría ser más condicionante para $\mathrm{PB}$, pero otras limitaciones posteriores a la producción de frutos y semillas podrían presentarse en PN.

Palabras clave: Depredación, fecundidad, fenología reproductive, limitación de semillas, remoción de semillas. 


\section{Introduction}

The production of seeds and their dispersion are critical processes for the population dynamics of tree communities in neotropical forests (Levin et al. 2003, Muller-Landau et al. 2008, Stoner \& Henry 2010). Low and uncertain seed production is a limitation for the transition in sufficient quantities to subsequent stages of the biological cycle of populations and for the reproductive success (Schupp \& Fuentes 1995, Tufto et al. 1997, Clark et al.1998, de Steven \& Wright 2002, Muller-Landau et al. 2008). It has been shown that a high variability in seed production diminishes the interspecific competition, thus allowing for the coexistence of many species as well as for the promotion of a high diversity at multiple scales (Tilman 1994, Hurtt \& Pacala 1995, Hubbell et al. 1999, Schupp et al. 2002).

In rain forests, despite the production of abundant pistillate flowers with potential of fecundation, it is common that a limited number of seeds mature and spread (Larson \& Barrett 2000, Clark et al. 2004). This may happen for different reasons: 1) limited pollen availability (Larson \& Barrett 2000, Stoner \& Henry 2010), 2) deficiency in resource availability (Wright et al. 1999), and 3) losses pre dispersion by predators (Maron \& Gardner 2000, Hulme 2001). Many species overcome these limitations through different strategies in their reproductive characteristics (Herrera 1998, van ulft 2004, van Rheenen 2005, Wright et al. 2005a, Muller-Landau et al. 2008), which are associated with evolutionary processes such as abiotic and biotic interactions, endogenous factors and or phylogenetic relations (Wright \& Calderón 1995, Williams-Linera \& Meave 2002, Marques et al. 2004, Brearly et al. 2007).

The identification of reproductive phenological patterns from species groups, guilds, or conspecific individuals is key to understand the assemblages of vegetation communities, especially of those groups with very similar phylogenetic characteristics that coexist in similar habitats. High similarity in the availability of fruits for dispersion might increase intra and interspecific competition, with yet unknown consequences for future regeneration processes (Levin et al. 2003, Clark et al. 2004).

Such is the case of two morphotypes of the woody tree Brosimum rubescens Taub. (Moraceae). These morphotypes coexist in Terra firme forests of the Colombian Amazon. The species is a long-lived, shade tolerant, generalist species, which inhabits different landscapes over well-drained soils of the Amazonia (Marimon \& Felfili 2001, Duque et al. 2003, Palacios 2005, Rivera et al. 2006). These two morphotypes, locally named Palosangre negro (Black palosangre-BP) and Palosangre blanco (White palosangre-WP) differ mainly in their foliar structures but are similar in terms of size, weight, shape and color of fruits and seeds (Palacios 2005). The study of temporality and productivity of cyclical biological events of each morphotype will be fundamental to better understanding their regenerative niche and their coexistence in the same habitat. In this study we assessed whether possible differences in the reproductive phenology and final availability of seeds, contribute both to the coexistence and abundance of these two morphotypes in terra firme forests. Specifically, our research questions were: Are there differences in the reproductive phenology between the two morphotypes? And how does seed availability vary in each morphotype?

\section{Materials and methods}

\section{The studied especies}

Brosimum rubescens Taubert is a species from the Moraceae family (Berg 1972, Berg \& Simonis 2000) distributed in the tropical rain forests from America, being the Amazonia its center of dispersion, where it has been reported in terra firme forests (Duivenvoorden \& Lips 1993, Urrego 1997, Sánchez 1997, López \& Cárdenas 2002, Duque et al. 2003, Rudas \& Prieto 2005, Palacios 2005, Parrado-Roselli 2005, Rivera et al. 2006, Peñuela \& Pijache 2007). Adult trees reach the main canopy, with maximum heights of $30-35 \mathrm{~m}$ and up to $90 \mathrm{~cm}$ of diameter. It is considered as a shade-tolerant and long-lived species, typical of primary forests (Marimon \& Felfili 2001, Palacios 2005, Rivera et al. 2006). According to results from 14 to 18 years of growth data in permanent plots, the life cycle of this species could be between 450 - 700 years (Laurance et al. 2004), though recent studies based on radio carbon would support the higher limit (Vieira et al. 2011). Our data at the El Zafire Biological Station average $1 \mathrm{~mm}$ per year of diametric growth (Peñuela \& Jiménez, unpublished data).

Brosimum rubescens is a monoiceous tree, whose male and female reproductive structures occur in the same inflorescence. Though Berg \& Hijman (1999) suggest that inflorescences of Brosimum are adapted for insect pollination, in a phylogenetic study of Moraceae Datwyler \& Weiblen (2004) say that pollination syndrome of Brosimum is anemophilous; however, the pollination biology of many Moraceae is not known and observations of floral visitors are lacking, particularly in Sorocea and the tribe Dorstenieae (to which Brosimum belongs). Fruit is round and fleshy, light green when ripening, its diameter is about $2 \mathrm{~cm}$ and has one seed. Diameter of brown seeds is on average $1.5 \mathrm{~cm}$ and is covered with sweet and almost transparent mucilage. The germination is hypogeous and occurs in few days (usually within 15-20 days) because seeds are recalcitrant. Seedlings are abundant in the understory of terra firme forests, especially under the crown of maternal trees (Palacios 2005, Rivera et al. 2006).

A wide variety of frugivorous animals are potential dispersers of B. rubescens, including primates (Rodríguez et al. 1995, Palacios et al.1997, Defler 2003). In 2003, when occurred a massive fructification of this species in the study area, we observed flocks of parrots (Brotogeris sp.) consuming the fruits. Groups of Psittacidae, Ramphastidae, Cotingidae, Callithrichidae, and Cebidae have been reported removing sees of Brosimum utile (Parrado-Roselli 2005), and Quiróptera in Brosimum alicastrum (Acosta \& Aguanta 2006). We also have seen secondary dispersion of this species by small rodents (Proechimys sp.), which used fruits for the construction of burrows in terra firme forests.

\section{Study area}

The study was carried out in a 20-ha permanent plot of a terra firme forest located at the El Zafire Biological Station in the southern Colombian Amazon in a National Forest Reserve, bordering Brazil (400'00' $\mathrm{S}$ and 69 53' 57' W) (Figure 1). The studied forest is well conserved; it has about 650 trees greater than $10 \mathrm{~cm}$ of diameter at breast height (DBH) in 160 species per hectare. The most abundant species belong to the genera Eschweilera from the Lecythidaceae family (E. bracteosa, E. coriacea, and E. punctata), as well as the Woody tree Andiroba (Carapa guianensis). According to Caldas-Lang's 


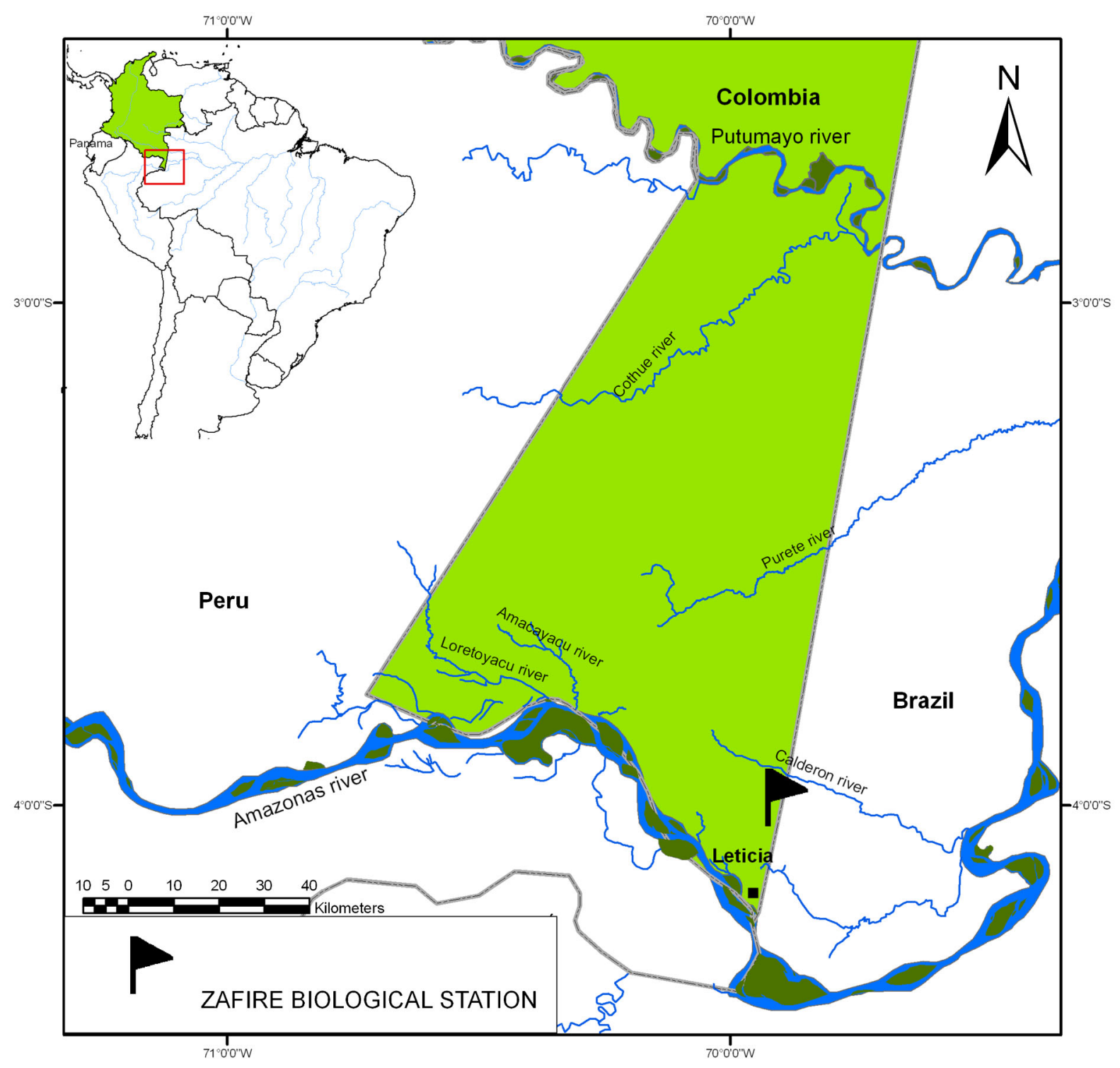

Figure 1. The El Zafire Biological Station study area (S $4^{\circ} 00^{\prime} 00^{\prime \prime}$, W $\left.69^{\circ} 53^{\prime} 57^{\prime \prime}\right)$ and National forests reserve in the Colombian Amazon (modified from Peñuela-Mora 2014).

climate classification (Rangel \& Luengas 1997), the study area is wet and warm with and average temperature of $27^{\circ} \mathrm{C}$ and an average annual rainfall varying between 2600 and $3400 \mathrm{~mm}$. The regime of precipitation is dominated by a rainy season from October to May and a dry season from June to August.

Geologically, the area belongs to the upper tertiary Mariñame formation, which forms the predominant subsoil of the Amazon basin (Arbeláez 2003) and is characterized by large sand deposits (Palacios 2005). Important variations in soils and topography are reported with altitude, which varies between 80 and $120 \mathrm{~m}$, and characterizes the terra firme forests with undulated, moderate to flat slopes. Soils are generally classified as Ultisols with medium to coarse sands and high quartz contents. These conditions result in a mostly sandy and sandy-loam texture dominating the region with clay loam soils in some areas. Soils are extremely acidic $(\mathrm{pH}<4.5)$, with very low CEC and total base saturation. Mineral elements such as calcium, magnesium, potassium, and sodium occur in minimal quantities, less than $0.2 \mathrm{meq} / 100 \mathrm{~g}$ (Arbeláez 2003).

\section{Tree selection for phenological monitoring}

All adult trees of $B$. rubescens were sampled in a 20-hectare plot previously established in primary forests. Botanical samples of both Brosimum morphotypes were collected and separated according to biological traits described by Palacios (2005). We selected trees with $\mathrm{DBH}>33.5 \mathrm{~cm}$, which were considered sexually mature and potentially fertile trees (PFT). To estimate the crown area (square meters) of each tree we measured 8 radii from the main stem of the tree (separated by an angle of $45^{\circ}$ ) to the projection of the crowns edge to the ground. Crown area was calculated as the sum of the areas of each of the triangles formed by two consecutive radii. Each month from February 2007 to January 2008 the phenological state of each tree was recorded. Phenophases were described as follows: flowering, when there were flowers in the crown or on the ground. Early fruiting, when fruits were harder and fertilized ovules showed no distinguishable seeds, and advanced fruiting, when pericardium fragments showing the cavity that 
holds the seeds or fruits with clearly differential seeds were found (Figure 2f).

\section{Trap sampling under parent trees}

Ten BP and six WP individuals displaying fertile activity were monitored; under each tree four traps were installed along cardinal points in the midpoint between the tree stem and the crown drip line. A total of 40 traps were located under BP and 24 under WP trees. Each trap of $1 \mathrm{~m}^{2}$ area was placed $0.50 \mathrm{~m}$ above the ground (Rozo-Mora \& Parrado-Roselli 2004, Parrado-Roselli et al. 2006). Trap content was collected every two weeks from September 2007 to January 2008 (8 samplings), during the main reproductive activity of both morphotypes. Samples were processed and analyzed at the Natural Products Lab of the National University of Colombia in Leticia.

\section{Laboratory processing}

Collected samples were oven dried at $103^{\circ} \mathrm{C}$ to constant weight. Reproductive structures were separated, counted and grouped into: inflorescences, unripe fruits, ripe fruits, damaged fruits (with holes or mechanical damage), empty fruits (those with diameter $\geqslant 1 \mathrm{~cm}$ and an empty cavity showing that there was at least one well developed seed (Figure $2 \mathrm{f}$ ), and free, ripe seeds (when well-developed free seeds were found). Each sample was weighted in analytical scale to the nearest $0.001 \mathrm{~g}$.

\section{Variables evaluated}

The absolute and relative density of actively fertile trees with relation to PFT was assessed for each morphotype. Because all reproductive structures of both morphotypes are green (even after ripening), it was extremely difficult to distinguish through observations with binoculars the change from inflorescence to fruit; for this reason, the level of synchrony of fertile activity was assessed from the percentage of individuals that started fertile activity (flowering only) and we did not determine this variable for fruting. Following Bencke \& Morellato (2002), a phenophase was considered synchronous when more than $60 \%$ of trees exhibited that

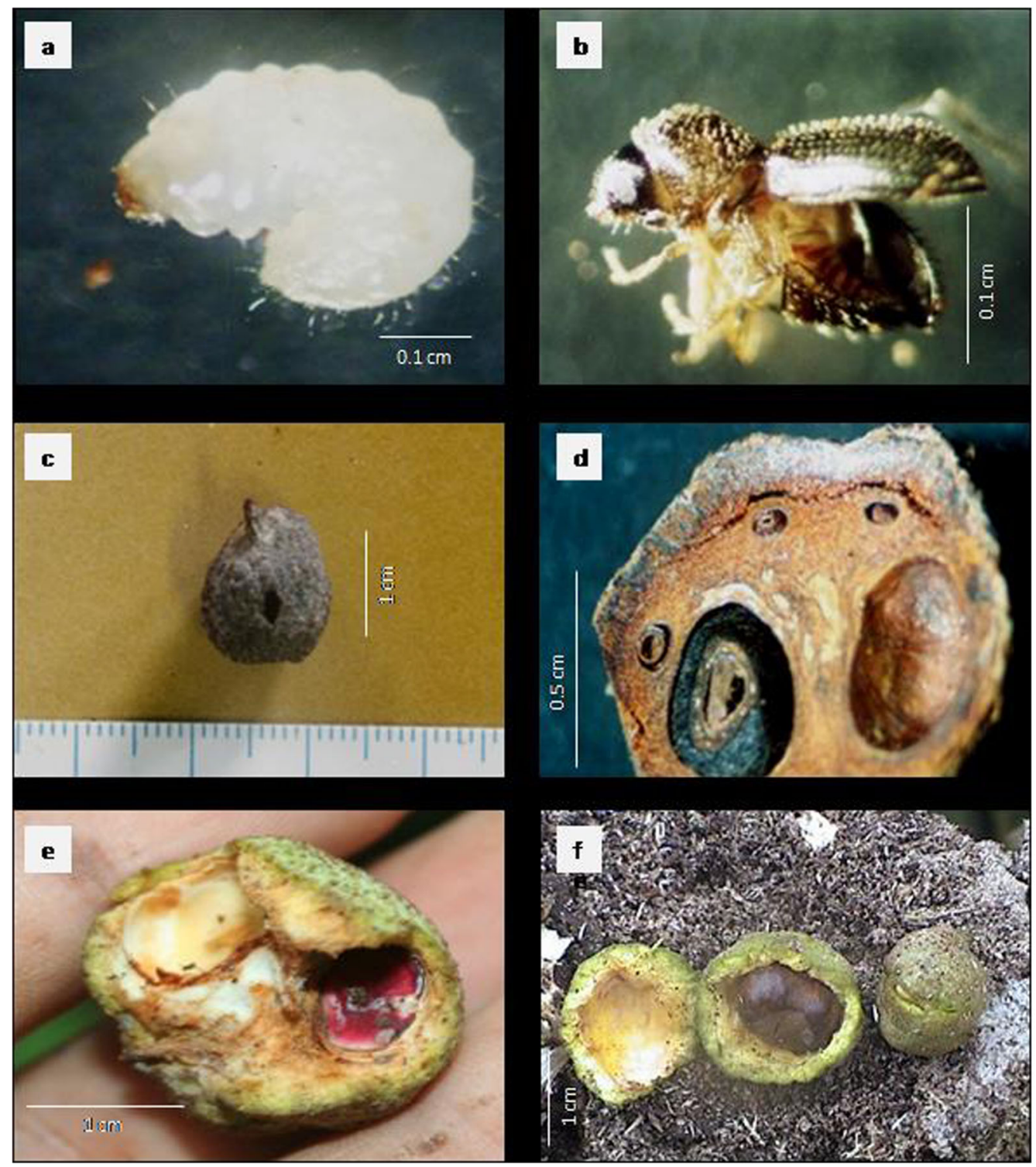

Figure 2. Fruits damaged in $\boldsymbol{B}$. rubescens. a and $\mathbf{b}$ Larvae and adult stages of Scolytidae. $\mathbf{c}$ and $\mathbf{d}$. Holes in seeds and fruits made by Scotylidae. e. Damage in fruits caused by vertebrate frugivores. f. Holes in fruits (pericarpium) suggesting that a well-developed seed developed inside the fruit. 
phenophase, with low synchrony if the phenophase occurred between $20 \%$ and $<60 \%$ of trees, and asynchronous if less than $20 \%$ of individuals showed the phenophase. Distances $(\mathrm{m})$ to the nearest potential reproductive neighbour was also determined, as well as distances to the nearest fertile neighbour.

Data from traps were used to quantitatively evaluate variables associated with flowering, fruiting, pre-dispersion fruit damage, seed production, seed removal, and biomass of reproductive structures per tree. In doing so, the average value of each variable per trap $\left(1 \mathrm{~m}^{2}\right)$ of each sampled tree was multiplied by the crown area of the tree. Unfertilized inflorescences were those fallen on the ground before pollination and captured in the traps and total number of inflorescences was the sum of infertile inflorescenes and total number of fruits produced.

For fruiting we defined the following variables: number of ripe fruits, those well-developed fruits with at least one seed or evidence of a well-developed ripe seed (Figures 2e and 2f); number of abortions, those structures with ovaries that fell down to the ground before ripping; total number of fruits, the sum of ripe fruits and abortions. Seeds were accounted as: removed seeds, fragments $(>50 \%)$ of empty fruits (pericarpium); free seeds, those well developed and morphologically viable; and total number of seeds, the sum of free seeds, ripe fruits, and removed seeds.

Predation was assessed in two classes: damaged fruits by insects, those with holes, and fruits damaged by frugivores, those with beaks and teeth marks, both in ripe and unripe fruits. To estimate the biomass of reproductive structures produced per tree in each monitoring period, we averaged the biomass collected in the four traps below each tree, which was then multiplied by the crown area of the respective tree.

\section{Data analysis}

For data analysis we used the software Statgraphics Centurion XVI.II. All data were tested for normality using the Shapiro-Wilk test. Non-normal data were log and square root- transformed. According to our research questions, we are interested in assessing differences in the reproductive phenology and seed availability between the two morphotypes of $B$. rubescens. Therefore, for all variables evaluated in this study (for example, $\mathrm{DBH}$, crown area, and distance to the nearest PFT, as well as the variables associated to reproductive phenology, such as flowering, incipient fruiting, and advanced fruiting, etc.) were compared with a Student's t-test, which allows to evaluate the null hypothesis of no differences between morphotypes. Variables associated to reproductive phenology were also compared using a Kolmogorov-Smirnov test, which allows to compare the differences between cumulative relative frequencies of two independent samples, especially when data numbers are reduced (Guisande et al. 2006). Finally, Pearson correlation analyses were carried out to test the correlation between observations of variables associated with reproductive phenology per tree along time.

\section{Results}

\section{Population of reproductive trees in the 20 ha plot}

There were 16 PFT of BP whose DBHs varied between 35.2 and $75.3 \mathrm{~cm}$, and 17 PFT of WP with DBHs between 34.4 and $75.4 \mathrm{~cm}$. Along the year of monitoring, twice of PFT of BP flowered in comparison to WP (Table 1). This phenophase was slightly synchronic in BP, with up to $43.8 \%$ of total PFT flowering in the same month. In WP flowering began 30 days later than in $\mathbf{B P}$ and was completely asynchronous, with values of up to $17.6 \%$. Distances between nearest PFT were not significantly different between morphotypes $(\mathrm{P}=0.345)$, with averages $( \pm \mathrm{SD})$ of $56.2 \pm 30.8 \mathrm{~m}$ in $\mathbf{B P}$ and $60.5 \pm 33.5 \mathrm{~m}$ in WP. However, distances between fertile trees were significantly different between morphotypes $(\mathbf{P}<0.000)$. In $\mathbf{B P}$ these distances were similar to those between PFT $(63.1 \mathrm{~m})$, while in WP they were greater $(92.3 \mathrm{~m})$.

\section{Flowering}

Flowering began in September 2007 in BP trees and 30 days later in WP trees. In both morphotypes maximum flowering occurred at the end of October and decreased gradually at the end of December for BP and at the end of November for WP (Figures $4 \mathrm{a}$ and $4 \mathrm{~b}$ ). In BP flowering was more conspicuous given the amount and size of inflorescences (mean $\pm \mathrm{SD}=5 \pm$ $0.4 \mathrm{~mm}$ ) than in $\mathbf{W P}$ (mean $=3 \pm 0.3 \mathrm{~mm}$ ). Temporal variation, evaluated through the cumulative relative frequencies of the total inflorescence production, was not statistically different between morphotypes (Kolmogorov Smirnov $\mathrm{KS}=1.2, \mathrm{P}=$ 0.09 ), as well as the variation of the number of unfertilized inflorescences $(\mathrm{KS}=0.8, \mathrm{P}=0.63)$ (Table 2). However, there was a positive correlation between unfertilized inflorescens and abortions $(\mathrm{r}=0.878, \mathrm{P}=0.041)$ and with fruit damage $(\mathrm{r}=0.800$, $\mathbf{P}=0.017$ ) in $\mathbf{B P}$, but no relationships were found in WP. No significant differences were found on infertile inflorescences between morphotypes, although average in $\mathbf{B P}$ was twice that of WP (21565 vs. 10240 inflorescences) (Table 4); however, in terms of percentage of total inflorescences, the trend was opposite: infertile inflorescences were significantly higher in WP than in BP $(79 \%$ vs. $0.29 \%)$, i.e. the morphotype with the smaller production of inflorescences had the higher percentage of infertile ones.

\section{Fruiting}

Temporal distribution of abortions was significantly different between morphotypes ( $\mathrm{KS}=2, \mathrm{P}=0.00$; Table 2$)$. At the end

Table 1. Total number of fertile trees per month of two morphotypes of Brosimum rubescens Taub. that came to fertile activity along one year of monitoring. The value in parenthesis is the relative monthly percentage of potentially fertile trees (PFT) that were active. The number in bold is the maximum percentage per morphotype.

\begin{tabular}{llllllllll}
\hline Morrphotype & $\begin{array}{l}\text { Total } \\
\text { PFT }\end{array}$ & Aug & Sep & Oct & Nov & Dec & Jan & $\begin{array}{l}\text { Fertile } \\
\text { activity }\end{array}$ & $\begin{array}{l}\text { Total } \\
\text { percentage }\end{array}$ \\
\hline Black palosangre (BP) & 16 & 0 & 4 & 7 & 3 & 0 & 0 & 14 & $87.5 \%$ \\
White palosangre (WP) & 17 & 0 & 0 & 3 & 3 & 1 & 0 & 7 & $41.2 \%$ \\
& & $(0 \%)$ & $(0 \%)$ & $(\mathbf{1 7 . 6})$ & $(\mathbf{1 7 . 6})$ & $(5.9 \%)$ & $(0 \%)$ & \\
\hline
\end{tabular}


Rivera L.E. et al.

Table 2. Results of the Kolmogorov-Smirnov statistical test comparing the cumulative distribution of relative frequencies for each reproductive phenological variable through time ( $n=8$ observations along a six-month period) between morphotypes of Brosimum rubescens Taub.

\begin{tabular}{|c|c|c|c|c|c|c|c|c|c|c|c|c|}
\hline \multirow[t]{2}{*}{ Variables } & \multicolumn{4}{|c|}{ Black palosangre (BP) } & \multicolumn{4}{|c|}{ White palosangre (WP) } & \multicolumn{4}{|c|}{ Kolmogorov-Smirnov } \\
\hline & SD & $\mathrm{VC} \%$ & MIN & MAX & SD & $\mathrm{VC} \%$ & MIN & MAX & MD & $\mathbf{K}-\mathbf{S}$ & $\mathbf{P}$ & $\mathbf{S}$ \\
\hline $\begin{array}{l}\text { Total number of } \\
\text { inflorescences }\end{array}$ & 5726 & 114 & 193 & 15553 & 2080 & 167 & 23 & 5246 & 0.6 & 1.2 & 0.09 & ns \\
\hline $\begin{array}{l}\text { Unfertilized } \\
\text { inflorescences }\end{array}$ & 3036 & 127 & 0 & 8257 & 2080 & 167 & 23 & 5245 & 0.4 & 0.8 & 0.63 & ns \\
\hline Number of abortions & 2715 & 107 & 121 & 7254 & 46 & 130 & 0 & 113 & 1.0 & 2.0 & 0.00 & $*$ \\
\hline Number of ripe fruits & 65 & 70 & 12 & 192 & 62 & 97 & 0 & 183 & 0.3 & 0.5 & 0.96 & ns \\
\hline $\begin{array}{l}\text { Number of damaged } \\
\text { fruits }\end{array}$ & 815 & 92 & 121 & 2101 & 34.1 & 98 & 0 & 85 & 1.0 & 2.0 & 0.00 & $*$ \\
\hline Number of free seeds & 27 & 91 & 0 & 71 & 17 & 118 & 0 & 44 & 0.4 & 0.8 & 0.63 & ns \\
\hline $\begin{array}{l}\text { Number of removed } \\
\text { seeds }\end{array}$ & 41 & 77 & 0 & 110 & 56 & 183 & 0 & 164 & 0.5 & 1.0 & 0.27 & ns \\
\hline Total number of seeds & 64 & 78 & 0 & 181 & 62 & 138 & 0 & 183 & 0.5 & 1.0 & 0.27 & ns \\
\hline $\begin{array}{l}\text { Biomass reproductive } \\
\text { structures }(\mathrm{g})\end{array}$ & 378 & 104 & 0 & 938 & 10 & 98 & 0.3 & 27.5 & 0.9 & 1.8 & 0.00 & $*$ \\
\hline
\end{tabular}

$\mathrm{SD}=$ Standard deviation, $\mathrm{VC} \%=$ variation coefficient; $\mathrm{MD}=$ maximum distance between cumulate distributions of both samples; $\mathrm{K}-\mathrm{S}=$ Kolmogorov-Smirnov statistic; $\mathrm{P}=\mathrm{P}$ value; $\mathrm{S}=$ statistical significance (statistical significant level $=0.05$ ). ns $=$ non-significant. ${ }^{*}=$ significant

of October there was a peak in abortions, coincident with flowering in $\mathbf{B P}$, whereas the peak occurred 30 days after the peak of flowering in WP. (Figure 4d). Ripe fruit production reached its maximum at the end of November, 30 days after maximum flowering. In WP it occurred in the middle of December, 45 days after peak flowering (Figures $4 \mathrm{c}$ and $4 \mathrm{~d}$ ). Relative distribution values of ripe fruits through time did not show significant differences between morphotypes $(\mathrm{KS}=0.5$, $\mathrm{P}=0.96$ ) (Table 2).

Some correlations were found between variables associated with reproductive phenology. In BP number of abortions was positively correlated with: infertile inflorescences $(\mathrm{r}=0.878$ and $\mathrm{P}=0.004)$, damaged fruits $(\mathrm{r}=0.984, \mathrm{P}=0.000)$, free seeds $(\mathrm{r}=$ $0.713, \mathrm{P}=0.047)$ and biomass of reproductive structures $(\mathrm{r}=$ $0.975, \mathbf{P}=0.000)$. In WP the number of abortions was correlated with damaged fruits $(\mathrm{r}=0.748, \mathrm{P}=0.033)$ and total seeds $(\mathrm{r}=$ 0.780 and $\mathrm{P}=0.023$ ) (Table 3).

The total number of fruits was significantly different between morphotypes $(\mathrm{P}=0.010)$, and much higher in $\mathbf{B P}$ (22448) than in WP (858) (Table 4). This difference is counteracted with $97 \%$ abortions (21743) in BP vs. $35 \%$ abortions (329) of fertilized ovules in WS $(\mathrm{P}=0.00)$. No statistical differences were found in total number of ripe fruits between morphotypes $(\mathrm{P}=0.506)$ as $\mathbf{B P}$ showed 705 ripe fruits and WP 528; however, in terms of percentage of ripe fruits WP showed higher values than BP (65\% vs. $3 \%)$ (Table 4$)$.

\section{Fruit predation}

Two types of damage were found for both morphotypes: a) damaged caused by insects in the larvae and adult stages of the Scolitydae family (Coleoptera), expressed by tissue necrosis and one or two small holes $(1-2 \mathrm{~mm})$ in unripe fruits, ripe fruits and inflorescences (Figures 2c, 2d) and b) damaged caused by vertebrates frugivores as evidenced by beak and teeth scars.

Damaged fruit fall for BP occurred at the beginning of October, concomitant, with the inflorescence fall, abortions, and fertilized inflorescences that increase towards the end of the month. The trend continued for about 30 days and then progressively diminished, whereas the production of ripe fruits and seeds increased (Figures 4c ,4e). Damage in fruits was found in October for WP, when abortions were also observed, and reached their maximum in the middle of November (Figures 4d, 4f). Temporal variation of damaged fruits was statistically different between morphotypes $(\mathrm{KS}=2, \mathrm{P}=0.00)$ (Table 2).

Mean number of damaged fruits was significantly different between BP (7061) and WP (308.2) $(\mathrm{P}=0.006)$ (Table 4). However, relative damaged in relation to the total number of fruits was not different between morphotypes (44.5\% vs. $37.5 \%$ ) $(\mathrm{P}=0.313)$ (Table 4). Damage caused by vertebrate frugivores in $\mathbf{B P}$ was $33 \%$ vs. $29 \%$ in WP and mainly affected the ripe fruits, whereas the damaged caused by Scolytidae was $62 \%$ and $71 \%$ respectively, mainly in unripe fruits (Figure $2 \mathrm{c}$ ). In BP the damage of fruits showed a strong correlation with the fall of infertile inflorescences $(\mathrm{r}=0.802, \mathrm{P}=0.017)$, abortions $(\mathrm{r}=$ $0.984, \mathrm{P}=0.000)$ and biomass of reproductive structures $(\mathrm{r}=$ $0.997, \mathrm{P}=0.000)$, whereas WP damage of fruits was correlated with abortions $(\mathrm{r}=0.812, \mathrm{P}=0.014)$ and ripe fruits $(\mathrm{r}=0.748$, $\mathrm{P}=0.033$ ) (Table 3).

\section{Production and removal of seeds}

Temporal variation of seed production showed a similar trend to the ripe fruit production in both morphotypes, with maximum numbers occurring towards the end of November in BP and towards the middle of December in WP (Figure $4 \mathrm{e}$ and $4 \mathrm{f})$. The temporal distribution of the number of free seeds was not significantly different between morphotypes $(\mathrm{KS}=0.8, \mathrm{P}=$ $0.63)$ as well as the total number of seeds produced $(\mathrm{KS}=1$, $\mathrm{P}=0.27$ ) (Table 2). The total number of seeds per tree showed non-significant differences between morphotypes $(P=0.396)$, with an average $( \pm \mathrm{SD})$ of $1382 \pm 705$ and $933 \pm 471$ seeds for BP and WP, respectively (Table 4). Of this total, 259 free seeds $(18.7 \%)$ in $\mathbf{B P}$ and $124(13.4 \%)$ in WP fell down beneath the parent tree, which added to the total number of ripe fruits produced (705 and 528, respectively), represented about $70 \%$ of all seeds produced (i.e. about $30 \%$ of seeds produced were 
Seed production of Brosimum rubescens

Table 3. Significant $(\mathrm{P}<0.05)$ correlation coefficients of Pearson for the temporal variation of each phenological variable in two morphotypes of Brosimum rubescens Taub (correlation: upper number, $\mathrm{P}$ value: lower number $(n=8)$ ).

\begin{tabular}{|c|c|c|c|c|c|c|c|c|c|}
\hline & & $\begin{array}{l}\text { Unfertilized } \\
\text { inflorescences }\end{array}$ & Abortions & $\begin{array}{l}\text { Ripe } \\
\text { fruits }\end{array}$ & $\begin{array}{l}\text { Damaged } \\
\text { fruits }\end{array}$ & $\begin{array}{l}\text { Free } \\
\text { seeds }\end{array}$ & $\begin{array}{l}\text { Removed } \\
\text { seeds }\end{array}$ & $\begin{array}{l}\text { Total } \\
\text { number } \\
\text { of seeds }\end{array}$ & $\begin{array}{l}\text { Biomass } \\
\text { (g) }\end{array}$ \\
\hline \multirow{13}{*}{ 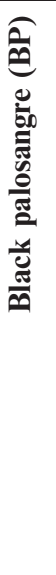 } & $\begin{array}{l}\text { Unfertilized } \\
\text { inflorescences }\end{array}$ & & & & & & & & \\
\hline & Abortions & 0.878 & & & & & & & \\
\hline & Ripe fruits & & & & & & & & \\
\hline & Domorod fruitc & 0.802 & 0.984 & & & & & & \\
\hline & Damaged iruits & 0.017 & 0.000 & & & & & & \\
\hline & Free seeds & & 0.713 & 0.746 & & & & & \\
\hline & Free seeds & & 0.047 & 0.034 & & & & & \\
\hline & Removed seeds & & & 0.991 & & 0.752 & & & \\
\hline & & & & 0.000 & & 0.031 & & & \\
\hline & Total number & & & 0.978 & & 0.859 & 0.980 & & \\
\hline & of seeds & & & 0.000 & & 0.006 & 0.000 & & \\
\hline & & 0.787 & 0.975 & & 0.997 & & & & \\
\hline & & 0.021 & 0.000 & & 0.000 & & & & \\
\hline \multirow{9}{*}{ 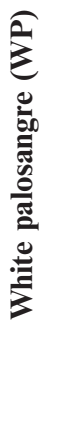 } & Unfertilized & & & & & & & & \\
\hline & Abortions & & & & & & & & \\
\hline & Ripe fruits & & & & & & & & \\
\hline & Damaged fruits & & 0.812 & 0.748 & & & & & \\
\hline & Free seeds & & 0.014 & 0.033 & & & & & \\
\hline & Removed seeds & & & & & & & & \\
\hline & Total number & & & 0.780 & & & 0.922 & & \\
\hline & of seeds & & & 0.023 & & & 0.001 & & \\
\hline & Biomass (g) & & & & & & & & \\
\hline
\end{tabular}

removed) (Table 4). These seeds are exposed to densedependent predation under the parental tree or to dispersion by secondary agents.

Of total seeds produced, 418 and 281 were removed in $\mathbf{B P}$ and WP, respectively; these data show that crown frugivory was about $30 \%$ in both morphotypes. According to the type of damage of reproductive structures that fell on the ground (a cavity inside the fresh and ripe pericarpium where a welldeveloped and morphologically viable seed was located), seed removal and the behaviour of vertebrate frugivores in the crowns were similar in both morphotypes (Figure 2e, 2f). Seed removal peaked at the end of November in $\mathbf{B P}$ and in the middle of December in WP (Figure 4e, 4f). However, temporal distribution was not significantly different between morphotypes $(\mathrm{KS}=1, \mathbf{P}=0.27$. Table 2$)$. In $\mathbf{B P}$ seed removal was correlated with the production of ripe fruits $(\mathrm{r}=0.991, \mathrm{P}=$ $0.000)$, free seeds $(r=0.752, P=0.031)$ and total of seeds $(r=$ $0.970, P=0.000)$. In WP seed removal was only correlated with the total number of seeds $(\mathrm{r}=0.932, \mathrm{P}=0.001)$ (Table 3$)$. The number of seeds removed did not show significant differences between morphotypes $(\mathrm{P}=0.72)$.

\section{Discussion}

\section{Availability of seed sources, fecundity and phenological variation}

Temporal variation of reproductive phenophases of $B$. rubescens was not different from the typical patterns of most tree species of humid tropical forests, characterized by flowering in the dry season and fruiting in the rainy season (ter Steege \& Persaud 1991, Rivera \& Borchert 2001, Chapman et al. 2005, Stevenson et al. 2008). Likewise, a similar pattern has been reported for other phylogenetically similar species, such as $B$. alicastrum, B. guianense, B. lactescens in forests of the Colombian Amazon (Stevenson et al. 2008). However, our results should be taken cautiously as much they are based on one year of observations, which is short because phenological behaviour might vary from year to year (ter Steege \& Persaud 1991, Williams-Linera \& Meave 2002, Marques et al. 2004).

Though the timing of flowering showed a slight discrepancy between morphotypes at the beginning of the phase, it showed synchrony at its maximum expression. However, timing of peaks of maximum production of ripe fruits and seeds were different (Figures $4 \mathrm{e}$ and $4 \mathrm{f}$ ). This phenological pattern would reduce competition between them and would enhance fruiting and seed dispersion at the beginning of the rainy season, when germination of $\boldsymbol{B}$. rubescens would be favored, given the recalcitrant condition of their seeds, as well as growth and survival of seedlings (Rivera et al. 2006).

The sample size (17 and 16 PFT of BP and WP, respectively) seems low for making conclusions on phenology and reproductive biology of the entire population of a species. However, this is the number of PFT of each morphotype found in a mega plot of 20 ha, which is a big sampling area in comparison with most of studies in tropical forests. The main reason for this limitation is the low density of trees of most 
Rivera L.E. et al.

Table 4. Statistical results per tree for reproductive variables of two morphotypes of Brosimum rubescens Taub. Significant differences $(\mathrm{P}<0.05)$ with the t test in bold. Highlighted are variables expressed as percentage of totals. SD: standard deviation.

\begin{tabular}{|c|c|c|c|c|c|c|c|c|c|}
\hline \multirow[t]{2}{*}{ Variables } & \multicolumn{3}{|c|}{ Black palosangre (BP) } & \multicolumn{5}{|c|}{ White palosangre (WP) } & \multirow{2}{*}{$\begin{array}{l}\mathrm{t} \text { test } \\
\mathrm{P}\end{array}$} \\
\hline & Mean & SD & Min & Max & Mean & SD & Min & $\operatorname{Max}$ & \\
\hline Total number of inflorescences & 44013 & 35988 & 2538 & 149688 & 11097 & 11416 & 1232 & 29422 & 0.074 \\
\hline Number of infertile inflorescences & 21565 & 42235 & 288 & 128484 & 10240 & 10826 & 616 & 27321 & 0.438 \\
\hline Total number of fruits & 22448 & 21120 & 1819 & 63206 & 858 & 742 & 142 & 2102 & 0.010 \\
\hline$\%$ fructification & 0.71 & 0.27 & 0.14 & 0.94 & 0.21 & 0.23 & 0.01 & 0.50 & 0.002 \\
\hline Number of abortions & 21743 & 20539 & 1729 & 61506 & 329 & 364 & 35 & 947 & 0.009 \\
\hline$\%$ abortion & 0.97 & 0.02 & 0.91 & 1.00 & 0.35 & 0.16 & 0.19 & 0.57 & 0.000 \\
\hline Number of ripe fruits & 705 & 636 & 0 & 1700 & 528 & 399 & 105 & 1154 & 0.506 \\
\hline$\%$ ripe fruits & 0.03 & 0.02 & 0.00 & 0.09 & 0.65 & 0.16 & 0.43 & 0.81 & 0.000 \\
\hline Number damaged fruits & 7061 & 6012 & 1472 & 22287 & 308.2 & 243.4 & 47.3 & 710.4 & 0.006 \\
\hline Relative fruit damage $(\%)$ & 44.5 & 23.2 & 18.8 & 80.9 & 37.5 & 4.3 & 33.3 & 42.9 & 0.313 \\
\hline Total number of seeds & 1382 & 705 & 0 & 1683 & 933 & 471 & 95 & 1036 & 0.396 \\
\hline Number of free seeds & 258.6 & 241 & 0 & 629 & 123.9 & 88.8 & 0 & 236.8 & 0.136 \\
\hline$\%$ free seeds & 0.20 & 0.10 & 0.11 & 0.44 & 0.13 & 0.08 & 0.00 & 0.20 & 0.162 \\
\hline Number of removed seeds & 418 & 415 & 0 & 1097 & 281 & 304 & 59 & 799 & 0.463 \\
\hline$\%$ removed seeds & 0.26 & 0.10 & 0.00 & 0.33 & 0.30 & 0.14 & 0.13 & 0.50 & 0.574 \\
\hline Fruit biomass (g) & 3188 & 3987 & 89 & 10394 & 83 & 63 & 14 & 189.4 & 0.036 \\
\hline $\mathrm{DBH}(\mathrm{cm})$ & 55.7 & 12.3 & 36.9 & 75.3 & 56.4 & 13.5 & 38 & 75.4 & 0.496 \\
\hline Crown area $\left(\mathrm{m}^{2}\right)$ & 60.3 & 19.9 & 20.1 & 82.4 & 75.6 & 23.4 & 47.3 & 118.4 & 0.214 \\
\hline
\end{tabular}

species in tropical forests, which makes difficult and extremely expensive the monitoring of large samples due to the extensions that would need to be covered.

Quantitative analyses of flowering showed that annual production of inflorescences was not statistically different between morphotypes. Nevertheless, the proportion of unfertilized inflorescences in relation to the total was different, since in BP it was about half of that in WP (49\% and $92.3 \%$, respectively) (Table 4). This result suggests certain inability for effective pollination in WP, which could suggest a limitation of pollination as a consequence of a greater effective distance between active PFT in the last one ( $92.3 \mathrm{~m}$ as compared to $63.1 \mathrm{~m}$ in BP) despite distances between PFT were similar $(\mathbf{B P}=56.2 \mathrm{~m}$ and $\mathbf{W P}=60.5$ $\mathrm{m})$. Greater distances between fertile trees have the potential to negatively affect pollination and therefore the number of fruits and seeds at the end of the cycle (Murcia 2002). Greater density of trees with fertile activity in BP $(>87 \%$ of PFT) probably increased the rate of pollination by insects and wind due to the shorter distance between reproductive trees and subsequently the greater probability of fecundation as compared to WP.

On the other hand, abortions were significantly higher in BP ( $97 \%$ of total number of fruits) as compared to WP (35\%). The abortion of young fruits is common due to self-incompatibility when self-pollination occurs (Bawa \& Webb 1984). This could be the case in monoiceous species such as B. rubesecens when flower production is high; under such conditions pollinators are easily satiated in a single tree, which increases the chances of self-pollination. Although this hypothesis was not tested in this study, it is a plausible explanation for the high level of abortion in BP, whose number of inflorescences was four times that in WP. However, abortions could also result as a consequence of a Scotylidae attack in inflorescences and unripe fruits (Figure 2). As a result of these processes, annual production of fruits and seeds was similar for the two morphotypes (Table 4), although the energetic cost was much lower for WP. The lack of a significant relationship between the production of inflorescences with that of fruits and seeds
(Table 3) suggests that the strategies for fruiting seemed to be different between morphotypes, with rates of transition between phases in BP mainly controlled by predation and abortion. Therefore, the higher number of flowers does not necessarily mean a higher number of fruits and seeds (Roberson \& Mac Nair 1995).

\section{Predation effects on the availability of fruits and seeds}

Predation of ripe fruits and seeds before dispersion highly affected the availability of fruits for primary dispersion (Table 4), as reported for other neotropical tree species (Janzen \& VasquezYanes 1991, Forget et al. 1999, Hulme 2001). The pattern of damage was similar between morphotypes and was probably associated with fruit similarity (Figure $3 \mathrm{c}$ and $3 \mathrm{~d}$ ) and the coexistence in the same habitat (Wright et al. 1999). Damage caused by vertebrate frugivores mainly occurs on ripe fruits, probably by primates and birds, which have been reported consuming Brosimum fruits (Defler 2003, Stevenson et al. 2000, Parrado-Roselli 2005), as well as by bats. Insect damage associated with immature reproductive parts could be related to the time required for larvae to complete their life cycle and emerge before being consumed by vertebrates along with the fruits (Restrepo 2002, Wright et al. 2005b).

Early attack of Scolytidae (Coleoptera) could be responsible for the massive abortion, mainly in BP (Table 4), because probably it is unfavorable to develop and mature a high number of unripe fruits infested by larvae. This type of relationship with predators supports the satiation hypothesis (Auspurguer 1981, Shupp 1992), which states that a high production of fruits increases the predator satiation and consequently a large number of seeds could reach maturity evading an attack.

\section{Seed removal by frugivores}

Close to $30 \%$ of seeds produced were removed from tree crowns of the two morphotypes. Beak and teeth scars in the reproductive structures, mainly in ripe fruits (Figure 2), and a 


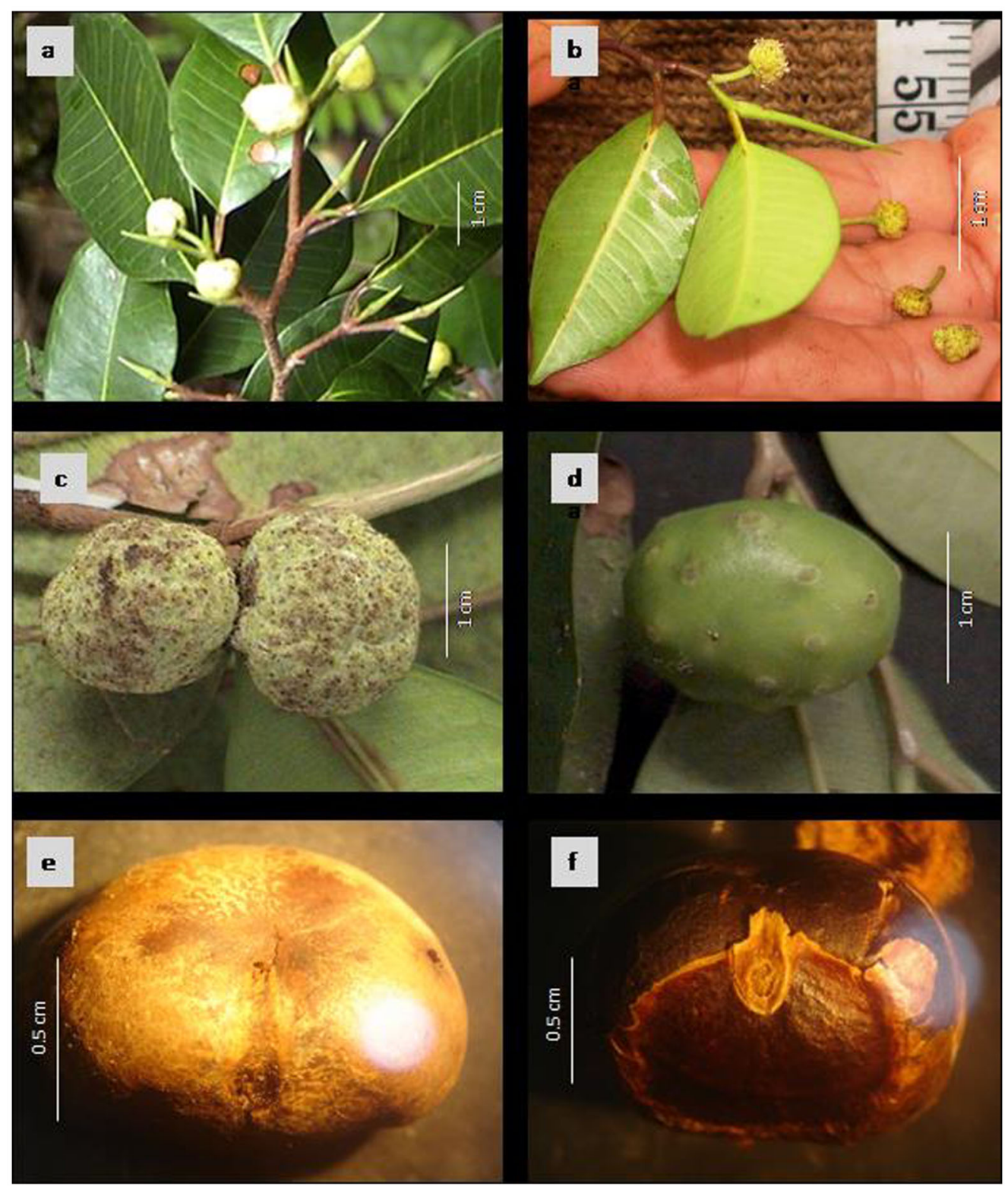

Figure 3. Reproductive structures of two morphotypes of $\boldsymbol{B}$. rubescens. BP at the left and WP at right. a and $\mathbf{b}$. Leaves and pistillate inflorescences. $\mathbf{c}$ and $\mathbf{d}$. Well-developed fruit structures almost ripe. e and $\mathbf{f}$. Ripe fruits.

similar number of removed seeds in both morphotypes (Table 4) suggest a similar behaviour of frugivores. These results are probably due to the high similarity in size, weight, and colour of fruits and seeds (Figure 3) (Restrepo 2002), even though the morphology of the two morphotypes is strictly different (Palacios 2005).

Various species of monkeys and parrots from the genus Brotogeris have been reported as B. rubescens consumers and potential dispersers (Stevenson 2002, Defler 2003, Rivera, pers. obs.). Groups of Psittacidae, Ramphastidae, Cotingidae, Callithrichidae and Cebidae have also been reported as removing seeds from B. utile (Parrado-Roselli 2005), and Quiroptera in B. alicastrum (Acosta \& Aguanta 2006). According to the theory of no frugivore-specialization (Hubbell et al. 1999, Terborgh et al. 2002), the availability of a wide group of frugivores would give $B$. rubescens an adaptive advantage for dispersion.
In neotropical forests, there is a strong seasonality in the annual supply of available fruits for the frugivores associated with rains. Therefore, a shortage season occurs in the dry season and an abundant one in the rainy season (Borchert 1998, Wright \& Van Schaik 1994, Stevenson et al. 2000, ParradoRoselli 2005, Stevenson et al. 2008). Availability of ripe fruits and seeds, coincident in the two morphotypes of B. rubescens, with the abundant season (Table 4), would allow them to share several fruit consumers. Conversely during the dry season, there is less overlap between diets of animals (Terborgh 1986). However, competition between morphotypes of B. rubescens by frugivores could be reduced by the slight temporal variation of seed production peaks between them (Figure $4 \mathrm{c}$ and $4 \mathrm{~d}$ ) and by the wide offer of potential frugivores during this season. The high number of removed seeds (Table 4) highlights the important role that frugivores play in the fitness of these two morphotypes. 


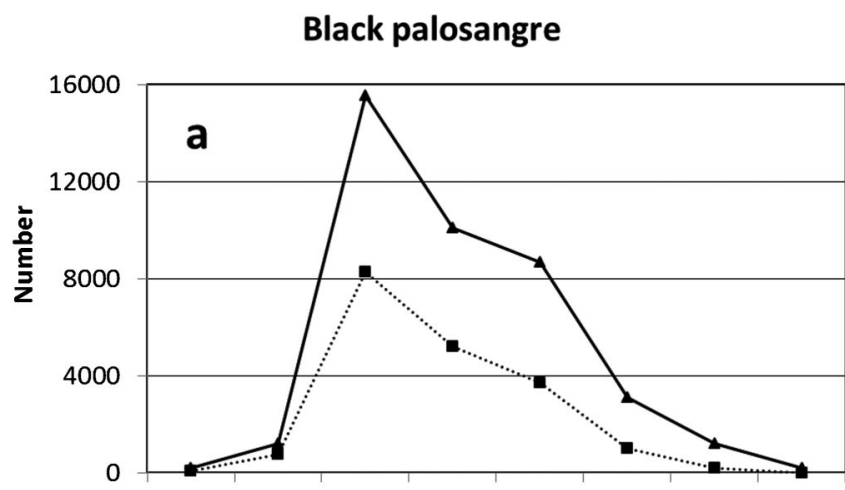

Sep-30 Oct-01 Oct-30 Nov-15 Nov-30 Dec-15 Dec-30 Jan-30 Date

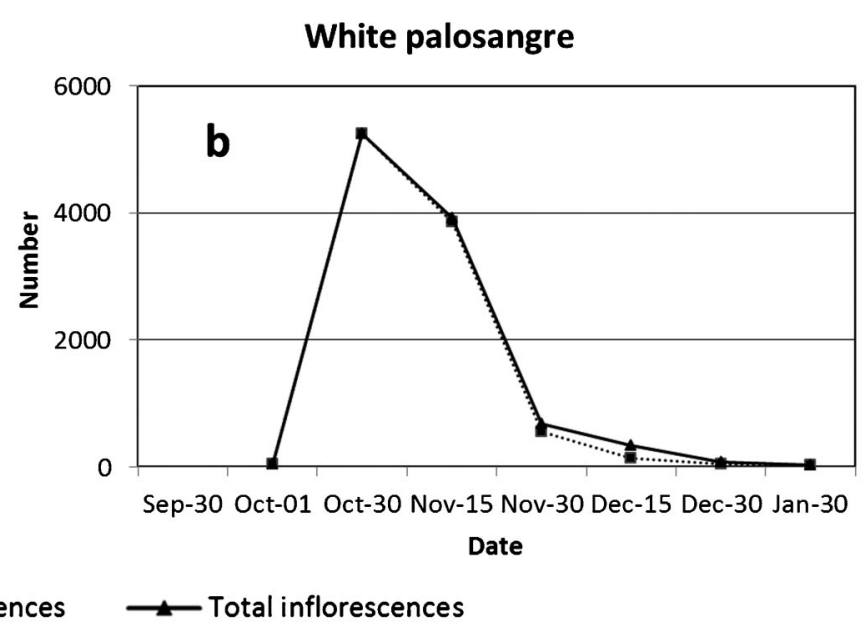

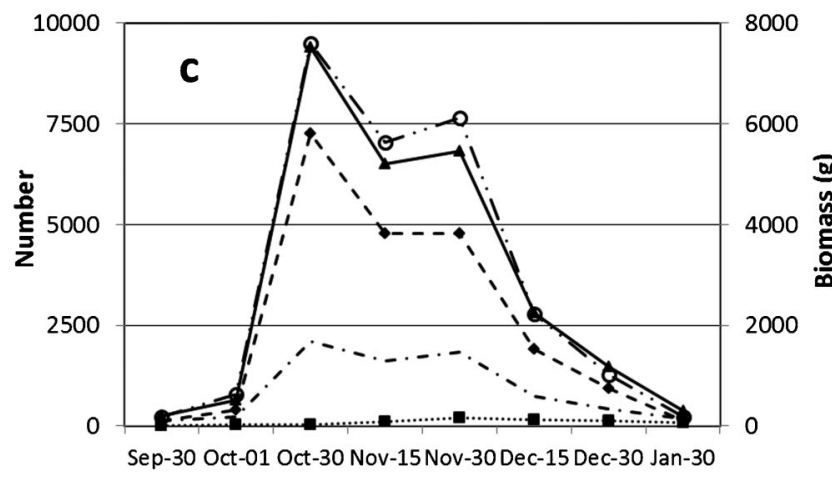

Date
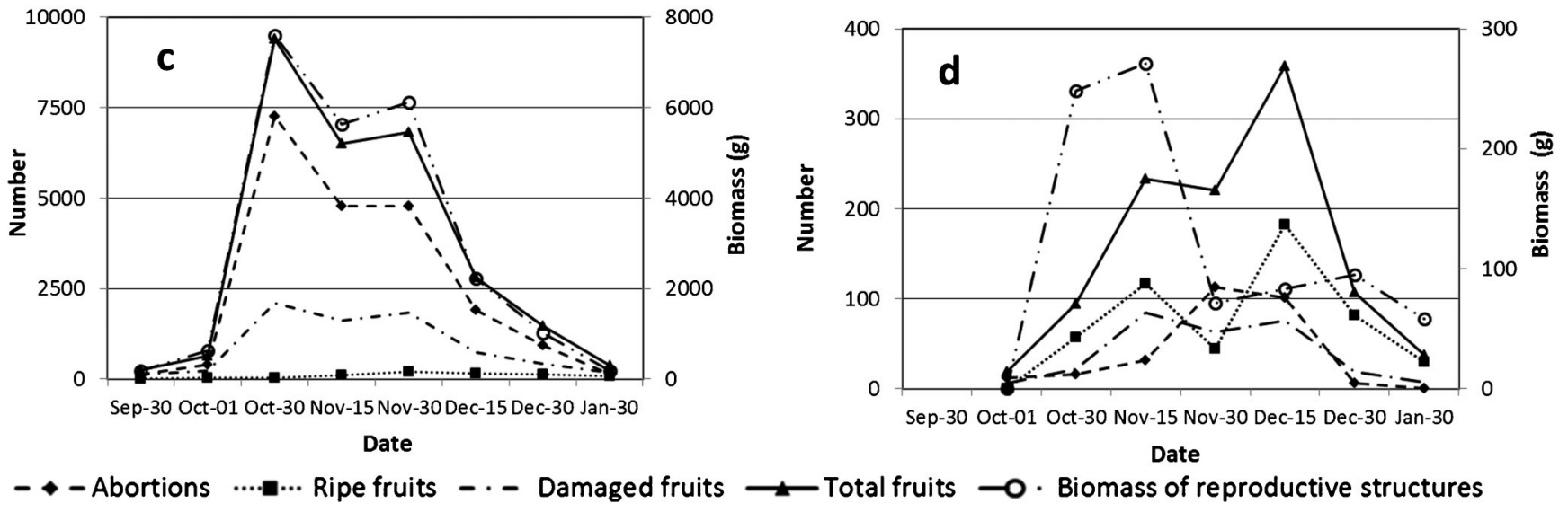

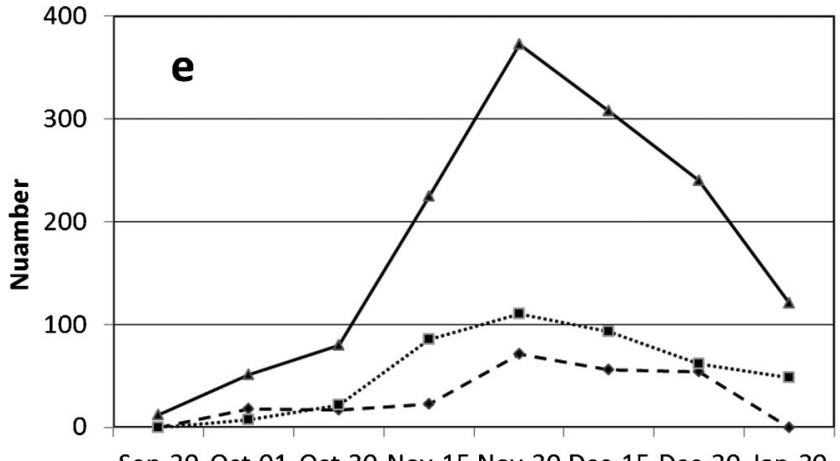

Sep-30 Oct-01 Oct-30 Nov-15 Nov-30 Dec-15 Dec-30 Jan-30

Date

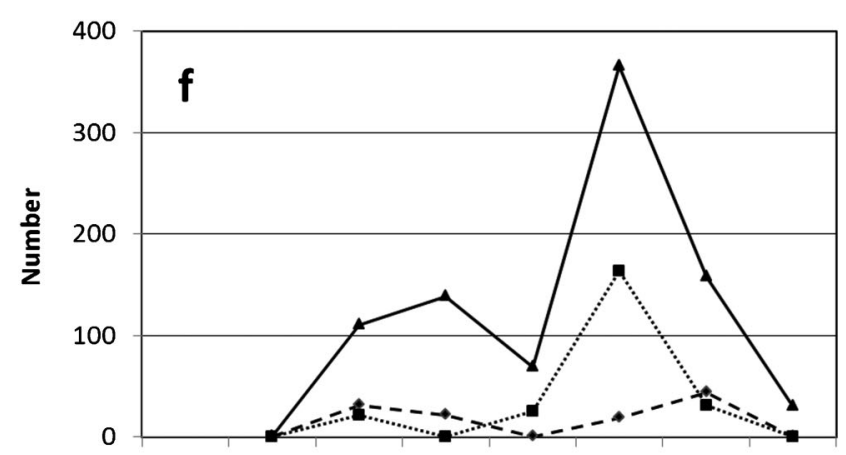

Sep-30 Oct-01 Oct-30 Nov-15 Nov-30 Dec-15 Dec-30 Jan-30

Date

$-\leftarrow$-Free seeds $\quad \cdots \cdot \cdot \cdot \cdot$ Removed seeds $\quad \longrightarrow$ Total seeds

Figure 4. Temporal course of variables describing reproductive phenology of two $\boldsymbol{B}$. rubescens morphotypes. Each value shows the average by tree. $\mathbf{a}$ and $\mathbf{b}$. Total number of inflorescences vs. infertile inflorescences. c and $\mathbf{d}$. Total number of fruits, ripe fruits, abortions, damaged fruits, and biomass of reproductive structures e. and $\mathbf{f}$. Total number of seeds, removed seeds, and free seeds.

\section{Conclusions}

The availability of potential seed sources was similar between morphotypes, as well as the seed production per fertile tree. However, a low number of PFT of WP went into fertile activity over the annual cycle. Therefore, it is more probable that WP shows seed limitations than does BP. Given that population structure is similar for both morphotypes, other processes after fruit and seed production should be occurring in BP to make similar the number of individuals between them.

Both morphotypes showed similar production of ripe fruits and viable seeds available for primary dispersion thanks to niche separation by adopting slightly different reproductive strategies, which probably diminishes competition 
between morphotypes and allow the coexistence over the same habitats.

In $\mathbf{B P}$ the strategy is to produce massive inflorescences and abortions during the fruiting phase, and by doing so, it satiates predators and produces enough viable seeds. On the other hand, WP fertilizes a significantly lower number of inflorescences and shows a reduced rate of abortions, with the result of a similar number of viable seeds to BP. This behavior corresponds to the pollination limitation hypothesis.

These findings imply that unplanned wood extraction via the harvest of reproductive trees would diminish the density of these individuals per unit area as well as the distance between reproductive neighbors. This probably will affect processes such as pollination, flowering, fruiting, fruit removal, dispersion and seedling establishment. To evaluate such effects on the local populations is important in the immediate future, particularly in WP, since effects of extraction probably will be more drastic in its populations by increasing pollination limitation and subsequently seed production.

\section{References}

ACOSTA, L.S. \& AGUANTA, F. 2006. Un nuevo aporte en el conocimiento de la dieta de los murciélagos frugívoros Artibeus lituratus y Artibeus jamaicensis. Kempffiana 2(1):127-133.

ARBELÁEZ, F. 2003. Spatial variation of fish communities among terra firme forest streams of the Colombian Amazonia. M.Sc Thesis, Universiteit van Amsterdam, Amsterdam.

AUSPURGUER, C.K. 1981. Reproductive synchrony of a tropical shrub: experimental studies on effects of pollinators and seed predators on Hybanthus prunifolius (Violaceae). Ecology 62:755-788.

BAWA, K.S. \& WEBB, CJ. 1984. Flower, fruit, and seed abortion in tropical forest trees: implications for the evolution of paternal and maternal reproductive patterns. Am. J. Bot. 71:736-751, http:// dx.doi.org/10.2307/2443371

BENCKE, C. \& MORELlATO, P. 2002. Comparação de dois métodos de avaliação da fenologia de plantas, sua interpretação representação. Rev Bras Bot 25(3):269-275, http://dx.doi.org/ $10.1590 / \mathrm{S} 0100-84042002000300003$

BERG, C.C. 1972. Flora Neotropica. Olmedieae, Brosimeae. Monograph No. 7. Hafner Publishing Company, Inc., New York

BERG, C.C., \& HIJMAN, E E. 1999. The genus Dorstenia (Moraceae). Ilicifolia 2:1-211.

BERG, C C. \& SIMONIS, J E. 2000. Flora de Venezuela, MoraceaeCecropiaceae. Instituto Botánico de Venezuela. Editorial Reflit C. A, Caracas.

BORCHERT, R. 1998. Responses of tropical tree to rainfall seasonality and its long-term changes. Climatic Change 39:381-393, http:// dx.doi.org/10.1023/A:1005383020063

BREARLEY, F.Q., PROCTOR, J., SURIANTATA, NAGY, L, DALRYMPLE, G. \& VOYSEY B.C. 2007. Reproductive phenology over a 10-year period in a lowland evergreen rain forest of central Borneo. J. Ecol. 95:828-839, http://dx.doi.org/10.1111/ j.1365-2745.2007.01258.x

CHAPMAN, C.A., CHAPMAN, L.J., ATRUHSAKER, T.T., ZANNE, A.E., CLARK, C.J. \& POULSEN, J.R. 2005. A longterm evaluation of fruiting phenology: importance of climate change. J. Trop. Ecol. 21:1-14, http://dx.doi.org/10.1017/ S0266467404001993

CLARK, J.S., MACKLIN, E. \& WOOD, L. 1998. Stages and spatial scales of recruitment limitation in southern Appalachian forests. Ecol. Monogr. 68:213-235, http://dx.doi.org/10.1890/0012-9615 (1998)068[0213:SASSOR]2.0.CO;2

CLARK, J.S., LADEAU, S. \& IBANEZ, I. 2004. Fecundity of trees and the colonization-competition hypothesis. Ecol. Monogr. 74:415-422, http://dx.doi.org/10.1890/02-4093
DATWYLER, S. \& WEIBLEN, G. 2004. On the origin of the fig: phylogenetic relationships of Moraceae from ndhf sequences. Am. Jour. Bot. 91(5):767-777, http://dx.doi.org/10.3732/ajb.91.5.767

DE STEVEN D, \& WRIGHT, J.S. 2002. Consequences of variable reproduction for seedling recruitment in three neotropical tree species. Ecology 83(8):2315-2327.

DEFLER, T.R. 2003. Primates de Colombia. Serie de Guías de campo. Conservación Internacional, Bogotá.

DUIVENVOORDEN, J.F. \& LIPS, J M. 1993. Ecología del paisaje del Medio Caquetá. Memoria explicativa de los mapas. Estudios en la Amazonia Colombiana. Tropenbos - Colombia, Bogotá.

DUQUE, A., CAVALIER, J. \& POSADA, A. 2003. Strategies of tree occupation at a local scale in terra firme forests in the Colombian Amazon. Biotropica 35(1):20-27.

FORGET, P.M., KITAJIMA, K. \& FOSTER, R.B. 1999. Pre and postdispersal seed predation in Tachigali versicolor (Caesalpinaceae): effects of timing of fruiting and variation among trees. J. Trop. Ecol. 15:61-81, http://dx.doi.org/10.1017/S026646749900067X

GUISANDE, G.C., BARREIRO, F.A., MANEIRO, E.I., RIVEIRO, A.I., VERGRA, C.A.R. \& VAAMONDE, L.A. 2006. Tratamiento de datos. Universidad de Vigo, Vigo.

HERRERA, C.M. 1998. Population-level estimates of inter-annual variability in seed production: what do they actually tell us? Oikos 82:612-616, http://dx.doi.org/10.2307/3546384

HUBBELL, S.P., FOSTER, R.B., O'BRIEN, S.T., HARMS, K.E., CONDIT, R., WECHSLER, B., WRIGHT, S.J \& LOO DE LAO S. 1999. Light-gap disturbances, recruitment limitation, and tree diversity in a neotropical forest. Science 283:554-557, http:// dx.doi.org/10.1126/science.283.5401.554

HULME, P.E. 2001. Seed-eaters: Seed dispersal, destruction and demography. In Seed dispersal and frugivory: ecology, evolution and conservation (Levey, D.J, Silva, W.R. \& Galetti, M. eds.). CABI Publishing, Wallingford, p. 257-273.

HURTT G.C. \& PACALA, S W. 1995. The consequences of recruitment limitation: reconciling chance, history and competitive differences between plants. J. Theor. Biol. 176:1-12, http:// dx.doi.org/10.1006/jtbi.1995.0170

JANZEN, D.H. \& VAZQUEZ-YANES, C. 1991. Aspects of tropical seed ecology of relevance to management of tropical forested wildlands. In Rain forest regeneration and management (GómezPompa, A., Whitmore, T.C. \& Hadley, M. eds.). UNESCO/ Parthenon, Paris, p. 137-157.

LARSON, B.M.H. \& BARRETT, S.C.H. 2000. A comparative analysis of pollen limitation in flowering plants. Biol. J. Linn. Soc. 69:503520, http://dx.doi.org/10.1111/j.1095-8312.2000.tb01221.x

LAURANCE, W., NASCIMENTO, H.E.M., LAURANCE, S.G., CONDIT, R., D' ANGELO, LAURANCE, SAMMYA \& ANDRADE, A. 2004. Inferred longevity of Amazonian rainforest trees based on a long-term demographic study. For. Ecol. Man. 190(2-3):131-143, http://dx.doi.org/10.1016/j.foreco.2003.09.011

LEVIN, S.A., MULLER-LANDAU, H.C., NATHAN, R. \& CHAVE, J. 2003. The ecology and evolution of seed dispersal: a theoretical perspective. Annu. Rev. Ecol. Evol. S. 34:575-604, http:// dx.doi.org/10.1146/annurev.ecolsys.34.011802.132428

LÓPEZ, R. \& CÁRDENAS, D. 2002. Manual de identificación de especies maderables objeto de comercio en la Amazonia colombiana. Instituto Amazónico de Investigaciones Científicas, SINCHI, Bogotá.

MARIMON, B.S. \& FELFILI, J.M. 2001. Studies in monodominant forests in eastern Mato Grosso, Brazil: ii. A forest in the areões Xavante indian reserve. Edinburgh Journal of Botany 58:483-497.

MARON, J.L. \& GARDNER, S.N. 2000. Consumer pressure, seed versus safe site limitation, and plant population dynamics. Oecologia 124:260-269.

MARQUES, M.C.M., ROPER, J.J. \& SALVALAGGIO, A.P.B. 2004. Phenological patterns among plant life-forms in a subtropical forest in southern Brazil. Plant Ecol. 173:203-213, http://dx.doi.org/ 10.1023/B:VEGE.0000029325.85031.90 
MULLER-LANDAU, H.C., WRIGHT, S.J., CALDERON, O., CONDIT, R. \& HUBBELL, S.P. 2008. Interspecific variation in primary seed dispersal in a tropical forest. J. Ecol. 96:653-667, http://dx.doi.org/10.1111/j.1365-2745.2008.01399.x

MURCIA, C. 2002. Ecología de la polinización. In Ecología y Conservación de bosques neotropicales (Guariguata, M. \& Kattan, G. eds.). LUR, San José, p. 493-530.

PALACIOS, P.A. 2005. Patrones estructurales y distribución espacial de poblaciones de Brosimum rubescens Taub. en relación con la variabilidad fisiográfica en la rivera colombiana del rio Amazonas. Tesis de Maestría, Universidad Nacional de Colombia, Sede Amazonia. Leticia.

PALACIOS, A.E., RODRÍGUEZ, A. \& DEFLER, T.R. 1997. Diet of group of Callicebus torquatuslugens during the annual resource bottleneck. Internat. Jour. Primat. 18(4):503-522, http://dx.doi.org/ 10.1023/A:1026307121583

PARRADO-ROSELLI, A. 2005. Fruit availability and seed dispersal in terra firme rain forests of Colombian Amazonia. Ph,D. Thesis, University of Amsterdam, Amsterdam.

PARRADO-ROSELLI, A., MACHADO, S.P. \& PRIETO-LOPEZ, T. 2006. Comparison between two methods for measuring fruit production in a tropical forest. Biotropica 38(2):267-271, http:// dx.doi.org/10.1111/j.1744-7429.2006.00125.x

PEÑUELA, M.C. \& PIJACHE, A. 2007. Densidad y estructura de 17 especies maderables en una megaparcela de 20 hectáreas en bosque de tierra firme. En: Actualidades Biológicas. Suplemento 1. Vol. 29. Resúmenes IV Congreso Colombiano de Botánica.

PEÑUELA-MORA, M.C. 2014. Understanding Colombian Amazonian White-Sand Forests. Ph.D. Thesis, Utrecht University, Utrecht.

RANGEL, O. \& LUENGAS, B. 1997. Clima y Aguas. In Zonificación ambiental para el plan modelo colombo-brasilero (eje ApaporisTabatinga: PAT) (IGAC, ed.). Linotipia Bolívar, Bogotá, Maryland, p. 49-68.

RESTREPO, C. 2002. Frugivoría. InEcología y Conservación de bosques neotropicales (Guariguata, M. \& Kattan, G. eds.). LUR, San José, p. 531-557.

RIVERA, G. \& BORCHERT, R. 2001. Induction of flowering in tropical trees by a 30 min reduction in photoperiod: evidence from field observations and herbarium collections. Tree Physiol. 21(4):201-212, http://dx.doi.org/10.1093/treephys/21.4.201

RIVERA, L.E., LÓPEZ, J.E. \& TRIANA, M.A. 2006. Efecto del sombreado en el crecimiento y mortalidad de plántulas de regeneración natural de Palosangre (Brosimum rubescens Taubert) en el sur del Trapecio Amazónico. Colombia Forestal 9:60-69, http://dx.doi.org/10.14483/udistrital.jour.colomb.for.2005.1.a05

ROBERSON, A.W. \& MAC NAIR, M.R. 1995. The effects of floral display size on pollinator service to individual flowers of Myosotis and Mimulus. Oikos 72:106-114, http://dx.doi.org/ $10.2307 / 3546044$

RODRÍGUEZ, M., J V., HERNÁNDEZ, J., DEFLER, T., ALBERICO, M., MAST, R, MITTERMEIER, R. \& CADENA, A. 1995. Mamíferos colombianos: sus nombres comunes e indígenas. Ocasional Paper no. 3. Conservation International, Washington, D. C.

ROZO-MORA, M.C., \& PARRADO-ROSELLI, A. 2004. Diurnal primary seed dispersal of Dacryodes chimantensis and Protium paniculatum (Burseraceae) in a tierra firme rain forest of Colombian Amazonia. Caldasia 6:11-124.

RUDAS, A. \& PRIETO, A. 2005. Flórula del Parque Nacional Natural Amacayacu, Amazonas, Colombia. Missouri Botanical Garden. Press., St. Louis.

SÁNCHEZ, M. 1997. Catalogo preliminar y comentado de la flora del Medio Caquetá. Estudios en la Amazonia colombiana XIII. Tropenbos - Colombia, Bogotá.

SCHUPP E.W. 1992. The Janzen-Connell model for tropical tree diversity: population implications and the important of spatial scale. Am. Nat. 140:526-530, http://dx.doi.org/10.1086/285426
SCHUPP, E.W. \& FUENTES, M. 1995. Spatial patterns of seed dispersal and the unification of plant population ecology. Ecoscience 2:267-75.

SCHUPP, E.W., MILLERON, T. \& RUSSO, S.E. 2002. Dissemination limitation and the origin and maintenance of species-rich tropical forests. In Seed dispersal and frugivory: ecology, evolution and conservation (Levey, D.J., Silva, W.R. \& Galetti, M. eds.). CAB International, Wallingford, p. 19-33.

STEVENSON, P.R. 2002. Frugivory and seed dispersal by woolly monkeys (Lagothrix lagothricha) in Tinigua National Park, Colombia. Ph.D Dissertation, State University of New York at Stony Brook, New York.

STEVENSON, P.R., CASTELlANOS, M.C., CORT, A.I. \& LINK, A. 2008. Flowering Patterns in a Seasonal Tropical Lowland Forest in Western Amazonia. Biotropica 40(5):559-567, http://dx.doi.org/ 10.1111/j.1744-7429.2008.00417.x

STEVENSON, P.R., QUIÑONES, M.J. \& AHUMADA, J.A. 2000. Influence of fruit availability on ecological overlap among four neotropical primates at Tinigua National Park, Colombia. Biotropica 32(3):533-544.

STONER K.E. \& M HENRY. 2010. Seed Dispersal and Frugivory in Tropical Ecosystems. In Encyclopedia of Life Support Systems: Tropical Biology and Natural Resources. UNESCO. http://www. eolss.net/outlinecomponents/International-Commission-TropicalBiology-Natural-Resources.aspx

TER STEEGE, H, \& PERSAUD, C.A. 1991. The phenology of Guyanese timber species: a comparison of a century of observations. Biotropica 10:194-210.

TERBORGH, J.T. 1986. Community aspects of frugivory in tropical forests. In Frugivores and Seed Dispersal (Estrada, A. \& Fleming, T.H. eds.). Junk, Dordrecht, p. 371-384.

TERBORGH, J.T., PITMAN, N., SILMAN, M., SCHICHTER, H. \& NÚÑEZ, P. 2002. Maintenance of tree diversity in tropical forest. In Seed dispersal and frugivory: ecology, evolution and conservation (Levey, D.J., Silva, W:R. \& Galetti, M. eds.). CAB International, Wallingford, pp. 1-17.

TILMAN, D. 1994. Competition and biodiversity in spatially structured habitats. Ecology 75:2-16, http://dx.doi.org/10.2307/ 1939377

TUFTO, J., ENGEN, S \& HINDAR, K. 1997. Stochastic dispersal processes in plant populations. Theor. Popul. Biol. 52:16-26, http:// dx.doi.org/10.1006/tpbi.1997.1306

URREGO, L.E. 1997. Los bosques inundables del medio Caquetá. Caracterización y sucesión. Estudios Amazonia colombiana XIV. Tropenbos - Colombia. Impreandes Presencia, Bogotá.

VAN RHEENEN, J. 2005. The role of seed trees and seedling regeneration for species maintenance in logged-over forest - a study in the Bolivian Amazon rainforest. Ph.D Dissertation, Universiteit Utrecht, Utrecht.

VAN ULFT, L.H. 2004. Regeneration in natural and logged tropical rain forest. Modelling seed dispersal and regeneration of tropical trees in Guyana. Tropenbos-Guyana Series 12,Tropenbos-Guyana Programme, Georgetown.

VIEIRA, S., TRUMBORE, S, CAMARGO, PB, SELHORST, D, CHAMBERS, J.Q, HIGUCHI N., \& MARTINELLI, L.A. 2011. LBA-ECO CD-08 Radiocarbon Dating of Tree Ages in Amazonas, Acre, and Para in Brazil. Data set from Oak Ridge National Laboratory Distributed Active Archive Center, Oak Ridge, Tennessee, U.S.A. http://daac.ornl.gov

WILLIAMS-LINERA, G. \& MEAVE, J. 2002. Patrones fenológicos. En Ecología y conservación de bosques neotropicales (Guariguata, M \& Kattan, G eds.). LUR. San José, p. 407-431.

WRIGHT, S.J., \& VAN SCHAIK C.P. 1994. Light and phenology of tropical trees. Am. Nat. 143:192-199, http://dx.doi.org/10.1086/ 285600

WRIGHT, S.J., \& CALDERÓN, O. 1995. Phylogenetic patterns among tropical flowering phenologies. J. Ecol. 83:937-948, http:// dx.doi.org/10.2307/2261176 
WRIGHT, S.J., CARRASCO, C., CALDERÓN, O. \& PATON, S 1999. The El Niño Southern Oscillation, variable fruit production and famine in a tropical forest. Ecology 80:1632-1647.

WRIGHT, S.J., JARAMILlO, M.A., PAVON, J., CONDIT, R., HUBBELL, S.P. \& FOSTER, R.B. 2005a. Reproductive size thresholds in tropical trees: variation among individuals, species and forests. J. Trop. Ecol. 21:307-315, http://dx.doi.org/10.1017/ S0266467405002294

WRIGHT, J., MULlER-LANDAU, H., CALDERON, O. \& HERNANDEZ, A. 2005b. Annual and spatial variation in seedfall and seedling recruitment in a neotropical forest. Ecology 86(4):848860, http://dx.doi.org/10.1890/03-0750 